\title{
Kompetensi Taruna dalam Melaksanakan Pembelajaran Online: Studi Kasus di Politeknik Ilmu Pemasyarakatan
}

\author{
Risyal Hardiyanto Hidayat \\ Manajemen Pemasyarakatan, Politeknik Ilmu Pemasyarakatan, Indonesia \\ risyalhardiyanto@gmail.com
}

\begin{abstract}
Abstrak
Penelitian ini bertujuan untuk mengetahui dan menggambarkan pelaksaanaan pembelajaran online yang ditinjau dari kompetensi taruna Politeknik Ilmu Pemasyarakatan (Poltekip) angkatan 52 prodi manajemen pemasyarakatan kelas B. Metode penelitian yang digunakan dalam penelitian ini adalah kuantitatif deskriptif dengan populasi seluruh taruna Poltekip angkatan 52 prodi manajemen pemasyarakatan kelas B. Teknik pengumpulan data dengan menggunakan studi pustaka. Pengujian validitas dilakukan dengan menggunakan koefisien korelasi product moment dari pearson yang pelaksanaannya menggunakan fasilitas komputer program SPSS for Windows versi 21. Uji reliabilitas dalam penelitian ini menggunakan pendekatan satu kali pengukuran (Single Trial Administration) dengan menggunakan rumus koefesien Alpha Cronbach. Hasil penelitian menunjukkan bahwa secara keseluruhan kompetensi taruna, sangat berkompeten dalam melaksanakan pembelajaran online, dilihat dari indikator-indikatornya yaitu knowladge, skill dan attitude.
\end{abstract}

Kata kunci: kompetensi, pembelajaran online.

Dikirim: 6 Mei 2020

Direvisi: 15 Juni 2020

Diterima: 26 Juni 2020

\section{Identitas Artikel:}

Hidayat, R. H. (2020). Kompetensi Taruna dalam Melaksanakan Pembelajaran Online: Studi Kasus di Politeknik Ilmu Pemasyarakatan. Jurnal Ilmu Pendidikan (JIP) STKIP Kusuma Negara, 12(1), 70-77.

\section{PENDAHULUAN}

Seluruh dunia sedang mengalami wabah Pandemi Covid-19 yang menyebar keseluruh negara-negara. Penyebaran virus corona ini diawali di negara China, pada awal kali muncul dan menyebar ke manusia berasal dari kota Wuhan yaitu pada akhir Desember 2019. Bahwa penyebaran awalnya beberapa orang yang terinfeksi memiliki riwayat yang sama, yaitu mengunjungi pasar basah makanan laut dan hewan lokal di Wuhan yang menjual hewan-hewan yang tidak biasa di makan oleh orang lain seperti ; tikus, kelelawar, ular dan hewan lainnya. Tercatat hampir seluruh kota di China terkena virus ini dari data pada 20 Maret 2020 sekitar 81.589 positif, 76.408 sembuh dan 3.318 mengalami kematian (Hidayat, 2020).

Hingga pada tanggal 2 Maret yang diumumkan Presiden Jokowi di Istana Negara bahwa dua orang di Indonesia positif terkena virus corona yang merupakan warga depok yaitu Ibu dan anaknya yang ditelusuri telah bertemu orang jepang yang terkena virus ini (Hidayat, 2020). Dengan terindikasi tersebut pemerintah Indonesia melakukan protokol kesehatan dalam memutus rantai persebaran virus corona dengan dikeluarkanya berbagai kebijakan dan perarturan untuk menekan persebaran. Namun sampai sekarang ini persebaran terus 
bertambah bahkan dalam update per tanggal 23 Maret 2020 sebesar 1.790, sembuh 112 dan mengalami kematian sebanyak 170 (Hidayat, 2020). Keadaan tersebut membuat pemerintahan memberlakukan social distancing dan physical distancing dengan bekerja, belajar, ibadah dari rumah sehingga sekolah, universitas, kementrian dan lembaga diliburkan atau dikurangi aktivitasnya, tak terkecuali Politeknik Ilmu Pemasyarakatan

Politeknik Ilmu Pemasyarakatan melakukan antisipasi penyebaran Covid-19 melalui Nota Dinas Nomor SDM.5.SM.09.03-661 tentang Pelaksanaan Belajar di Rumah (Study From Home) sehingga Poltekip melakukan kebijakan memulangkan seluruh taruna ke orang tuanya masing yang dimulai tanggal 14 Maret 2020, namun langkah tersebut bukan berarti proses belajar mengajar berhenti, melainkan tetap melakukan proses belajar mengajar dari rumah dengan metode pembelajaran online, dalam kegiatan pembelajaran online atau e-learning tidak saja materi pelajaran disediakan secara online, tetapi juga ditandai dengan adanya suatu sistem (berupa software) yang mengatur dan memonitor interaksi antara guru dan siswa (dosen dengan taruna), baik bersifat langsung atau tertunda (Arsyad, 2009), contohnya seperti penggunaan aplikasi Zoom, WA, Google Classroom dan lainya. Namun dalam pelaksanaanya masih ditemukan taruna yang mengalami kesulitan dengan metode pembelajaran melalui online tersebut dibandingkan dengan pembelajaran tatap langsung dikelas atau metode pembelajaran konvensional .

Kompetensi siswa atau taruna tidak akan pernah habis untuk dikaji. Hal ini dikarenakan kompetensi siswa atau taruna menjadi tujuan dari proses pendidikan, terutama pendidikan diploma disekolah kedinasaan. Karena PoliteknikIlmu Pemasyarakatan sebagai sekolah kedinasaan yang memiliki kuruikulum khusus yang lebih memfokuskan tarunanya untuk kepada berkarier pada bidang pekerjaan di Pemasyarakatan (Amalia \& Suwatno, 2016).

Noor \& Dola (2009) mengemukakan bahwa kompetensi dapat didefinisikan sebagai bakat yang diperlukan untuk meningkatkan kemampuan dasar dan untuk meningkatkan kinerja ke tingkat yang lebih tinggi lagi. Sementara Spencer \& Spencer (2008) menyatakan kompetensi seseorang merupakan dasar individu yang berhubungan dengan efektivitas kinerja dalam suatu pekerjaan. Di sini dapat disimpulkan bahwa kompetensi seseorang memiliki dampak langsung atas kinerja yang menjadi tanggung jawabnya. Tinggi tidaknya kompetensi seseorang akan berdampak pada kualitas hasil kinerjanya. Suatu kompetensi dapat diperoleh dengan proses aktualisasi pada individu itu sendiri, bisa melalui proses belajar, berdasarkan pengalaman, atau dengan melakukan tes uji coba untuk mengukur tingkat kompetensi yang dimilikinya dengan berdasarkan tiga komponen pembentuk kompetensi yaitu knowledge, skill, dan attitude (Hutapea, 2008)

Berdasarkan permasalahan di atas, maka dalam penulisan bertujuan untuk mengetahui dan menggambarkan pelaksaanaan pembelajaran online yang ditinjau dari kompetensi taruna Poltekip angkatan 52 prodi manajemen pemasyarakatan kelas B.

\section{METODE PENELITIAN}

Pada penelitian ini menggunakan pendekatan kuantitatif deskriptif dengan variabel tunggal yaitu kompetensi taruna Poltekip angkatan 52 prodi manajemen 
pemasyarakatan kelas $\mathrm{B}$ dalam melaksanakan pembelajaan online, dalam penelitian ini menggunakan keseluruhan dari populasi dengan karakteristik: (1) Taruna Politeknik Ilmu Pemasyarakatan Angkatan 52; (2) Taruna Prodi Manajemen Pemasyarakatan Kelas B.

Arikunto (2006) mengatakan bahwa populasi merupakan keseluruhan dari subyek penelitian dalam penelitian ini subyek yang digunakan yaitu keseluruhan populasi dalam penelitian ini dikarenakan jumlah taruna Poltekip angakatan 52 prodi manajemen pemasyarkatan kelas B berjumlah 42 siswa, namun ada 1 taruna dengan kriteria eksklusi. Metode pengumpulan data yang digunakan adalah metode angket (kuesioner) melalui google form. Metode angket atau kuesioner adalah teknik pengumpulan data yang dilakukan dengan cara memberilan pertanyaan atau penyataan tertulis kepada responden untuk dijawab. Di dalam google form yang diberikan kepada responden dimuat jumlah pertanyaan 15 butir sesuai dengan operasional konsep teori kompetensi yang harus diisi responden dengan menggunakan skala likert yang pada setiap pertanyaan atau peryataan diungkapkan dengan kata-kata: Sangat Setuju (SS), setuju (S), Kurang Setuju (KS), Tidak Setuju (TS), Sangat Tidak Setuju (STS).

Uji validitas dilakukan dengan menggunakan korelasi product moment dari Pearson yang dihitung menggunakan piranti lunak SPSS 21. Reliabilitas menunjukkan sejauh mana hasil pengukuran dengan alat tersebut dapat dipercaya. Hal ini ditunjukkan oleh taraf keajegan (konsistensi) skor yang diperoleh oleh para subjek yang diukur dengan alat yang sama, atau diukur dengan alat yang setara pada kondisi yang berbeda (Suryabrata, 2002; 2010). Uji reliabilitas dalam penelitian ini menggunakan pendekatan satu kali pengukuran (Single Trial Administration) dengan perhitungan Alpha Cronbach yang dihitung menggunakan SPSS 21.

Data dalam penelitian ini diolah menggunakan teknik statistik deskriptif yaitu menyajikan ukuran-ukuran kecenderungan sentral seperti tabel freukeunsi pada setiap indikatornya. Pada penelitian kuantitatif deskriptif, pengolahan data dilakukan berdasarkan pada analisis presentase dan analisis kecenderungan (Arikunto, 2006). Analisis data dilakukan untuk mendeskripsikan perilaku dalam populasi yang besar yakni kompetensi taruna dalam melaksanakan pembelajaran online. Teknik analisis deskriptif berupa penyajian data melalui tabel atau grafik. Perhitungan statistik deskriptif dilakukan menggunakan piranti lunak SPSS 21 for Windows.

\section{HASIL DAN PEMBAHASAN}

Kompetensi secara umum yaitu kemampuan yang dibutuhkan untuk melakukan suatu perkerjaan seperti halnya pembelajaran online yang dilakukan oleh Taruna Poltekip, dengan menunjukan adanya peningkatan kompetensi merupakan untuk meningkatkan taruna dalam melaksanakan pembelajaran secara efektif, efesien dan bertanggung jawab. Pengukuran Kompetensi taruna dalam melaksanakan pembelajaran online dalam hal ini menggunakan skala komptensi dengan hasil uji reliabilitas sebesar 0,774 dari 15 pertanyaan dalam kuisioner yang dilaksanakan, sehingg bahwa skala tersebut reliabel, karena koefisien reliabilitasnya mendekati angka 1,00 sehingga dapat digunakan sebagai alat pengumpulan data dalam 
penelitian (Azwar,2004). Berikut merupakan hasil analisa yang disajikan melalui Tabel 1.

Tabel 1. Hasil Analisis Reliabilitas

\begin{tabular}{|c|c|c|c|c|c|}
\hline \multicolumn{4}{|c|}{ Case Processing Summary } & \multicolumn{2}{|c|}{ Reliability } \\
\hline & & $\mathrm{N}$ & $\%$ & Cronbach's Alpha & $\mathrm{N}$ of Items \\
\hline & Valid & 41 & 100,0 & 0,774 & 16 \\
\hline Cases & Ecluded $^{\mathrm{a}}$ & 0 & 0,0 & & \\
\hline & Total & 41 & 100,0 & & \\
\hline
\end{tabular}

Tabel 1 menunjukkan bahwa uji validitas dan reliabilitas skala kecerdasan sosial dilakukan dengan menggunakan alat bantu program SPSS (Statistical Product and Service) versi 21. Hasil uji coba terpakai, instrumen pengukuran kompetensi taruna dalam pembelajaran online yang dikembangkan dalam penelitian ini menunjukkan bahwa dari 15 butir skala yang diuji validitasnya, semuanya 15 butir pertanyaan valid tingkat signifikansi 0,01 .Uji reliabilitas skala kompetensi taruna menggunakan teknik statistik cronbach's alpha diperoleh koefisien reliabilitas sebesar 0,774. Sehingga intrumen kompetensi taruna dinyatakan memiliki reliabilitas dengan taraf baik.

Selanjutnya dapat di kategorikan responden berdasarkan jenis kelamin dan umur dengan jumlah 41 Taruna yang dijadikan sebagai responden, yaitu berturutturut pada Gambar 1 dan Gambar 2.

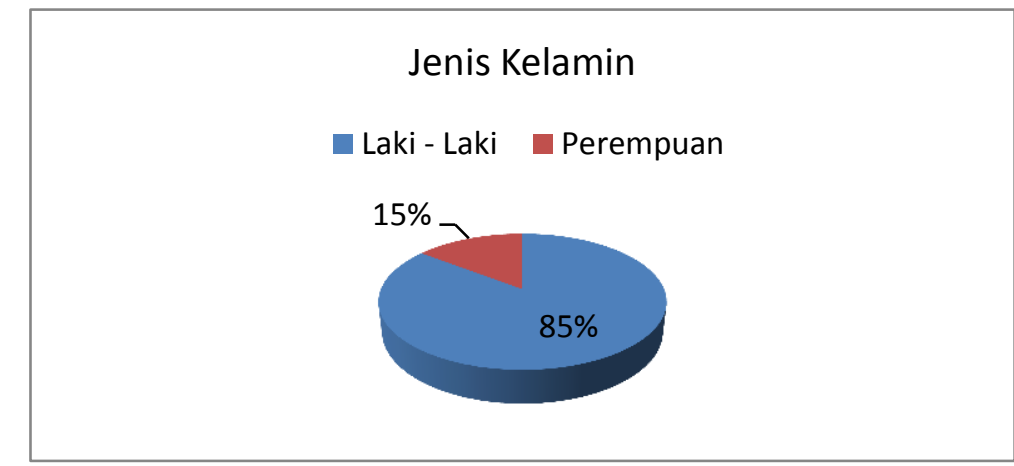

Gambar 1. Karakteristik Responden Berdasarkan Jenis Kelamin

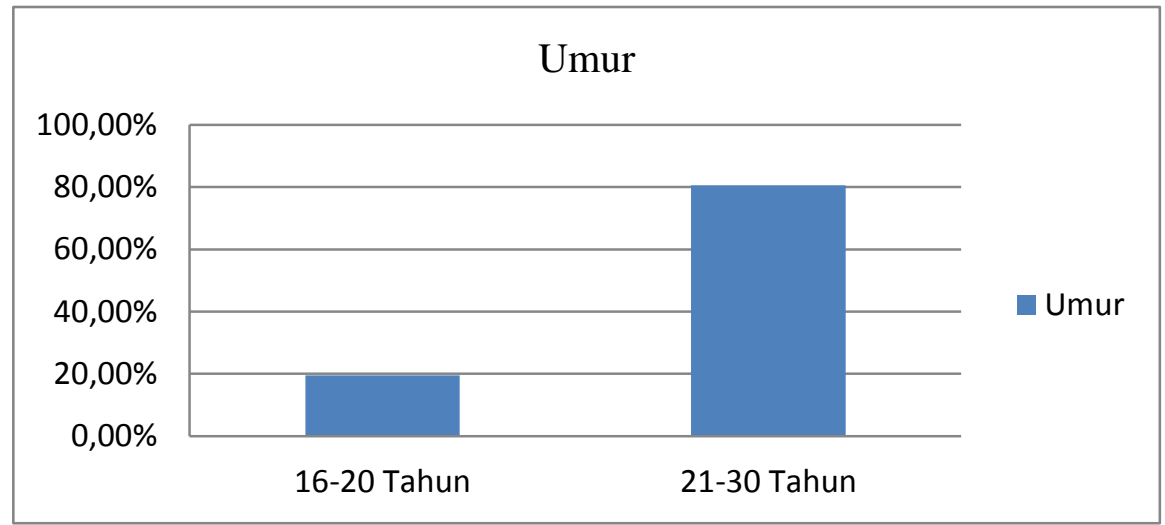

Gambar 2. Karakteristik Responden Berdasarkan Umur 
Pada penelitian ini, penyajian jenis kelamin dan umur untuk menggambarkan bahwa responden sebanyak 41 orang merupakan bukti quisiner yang dilakukan benar adanya prodi manajemen pemasyarakatan kelas B. berdasarkan jenis kelamin dalam melihat gambar responden laki-laki lebih banyak daripada perempuan, yang terdiri dari 35 laki-laki $(85 \%)$ dan 6 perempuan $(15 \%)$ sehingga selisih antara responden laki-laki dan perempuan sebesar (70\%). Sedangkan pada karakteristik responden dibagi menjadi 2 kelompok yakni rentang umur responden 16-20 tahun dan 21-30 tahun. Dalam gambar 3 dapat dilihat bahwa (20\%) responden berumur 16-20 tahun, (80\%) responden berumur 21-30 tahun.

Untuk menggambarkan kompetensi taruna dengan gambar freukeunsi berdasarkan komponen pembentuk kompetensi yaitu knowledge, skill dan attitude yang hasilnya didapatkan dari setiap pertanyaan yang sudah digolongkan indikator kompetensi tabel berikut.

Tabel 2. Distribusi Freukeunsi Kompetensi Taruna Berdasarkan Knowledge

\begin{tabular}{cccccc}
\hline & & Frekuensi & Persentase & Persentase Valid & Persentase Kumulatif \\
\hline \multirow{6}{*}{ Valid } & 1 & 3 & 1,5 & 1,5 & 1,5 \\
& 2 & 14 & 6,8 & 6,8 & 8,3 \\
& 3 & 56 & 27,3 & 27,3 & 35,6 \\
& 4 & 84 & 41,0 & 41,0 & 76,6 \\
& 5 & 48 & 23,5 & 23,4 & 100,0 \\
\cline { 2 - 5 } & Total & 205 & 100,0 & 100,0 & \\
\hline
\end{tabular}

Pada indikator knowladge taruna yang memilih sangat tidak setuju sebanyak $(1,5 \%)$, memilih tidak setuju sebanyak $(6,8 \%)$, memilih kurang setuju sebanyak $(27,3 \%)$, memilih setuju sebanyak $(41,0 \%)$ dan memilih sangat setuju sebanyak $(23,4 \%)$. Maka untuk indikator knowladge menunjukukan bahwa taruna memiliki kompetensi knowladge yang tinggi. Lubis \& Oktaviani (2015) menjelaskan bahwa pengetahuan atau knowledge adalah hasil tahu dari manusia yang sekedar menjawab pertanyaan "What". Pengetahuan merupakan hasil dari tahu, dan ini terjadi setelah orang melakukan penginderaan terhadap suatu objek tertentu.

Tabel 3. Distribusi Frekuensi Kompetensi Taruna Berdasarkan Skill

\begin{tabular}{cccccc}
\hline & & Frekuensi & Persentase & Persentase Valid & Persentase Kumulatif \\
\hline \multirow{6}{*}{ Valid } & 1 & 6 & 2,9 & 2,9 & 2,9 \\
& 2 & 5 & 2,4 & 2,4 & 5,3 \\
& 3 & 49 & 23,9 & 23,9 & 29,3 \\
& 4 & 81 & 39,5 & 39,5 & 68,8 \\
& 5 & 64 & 31,2 & 31,2 & 100,0 \\
\cline { 2 - 5 } & Total & 205 & 100,0 & 100,0 & \\
\hline
\end{tabular}

Selanjutnya pada indikator skill dalam melaksakana pembelajaran online yang dilihat dari banyaknya responden sebanyak 41 orang yakni, pada indikator skill taruna yang memilih sangat tidak setuju (2,9\%), memilih tidak setuju $(2,4 \%)$, memilih kurang setuju $(23,9 \%)$, memilih setuju $(39,5 \%)$, memilih sangat setuju $(31,2 \%)$ maka untuk indikator skill menunjukan bahwa taruna memiliki kompetennsi skill yang tinggi. Menurut Kandou (2016), keterampilan berarti 
mengembangkan pengetahuan yang didapatkan melalui training dan pengalaman dengan melaksanakan beberapa tugas.

Tabel 4. Distribusi Freukeunsi Kompetensi Taruna Berdasarkan Attitude

\begin{tabular}{cccccc}
\hline & & Frekuensi & Persentase & Persentase Valid & Persentase Kumulatif \\
\hline Valid & 1 & 7 & 3,4 & 3,4 & 3,4 \\
& 2 & 4 & 2,0 & 2,0 & 5,4 \\
& 3 & 31 & 15,1 & 15,1 & 20,5 \\
& 4 & 75 & 36,6 & 36,6 & 57,1 \\
& 5 & 88 & 42,9 & 42,9 & 100,0 \\
\cline { 2 - 5 } & Total & 205 & 100,0 & 100,0 & \\
\hline
\end{tabular}

Sedangkan Pada indikator attitude dalam melaksakana pembelajaran online yang dilihat dari banyaknya responden sebesar 41 orang yakni, pada indikator attitude memilih sangat tidak setuju $(3,4 \%)$, memilih tidak setuju $(2,0 \%)$, memilih kurang setuju $(15,1 \%)$, memilih setuju $(36,6 \%)$, memilih sangat setuju $(42,9 \%)$ maka untuk indikator attitude menunjukan bahwa taruna memiliki kompetennsi attitude yang sangat tinggi. attitude merupakan sikap terhadap obyek tertentu yang disertai dengan kecenderungan untuk bertidak sesuai dengan sikap terhadap obyek tadi atau dengan kata lain yang lebih singkat sikap atau attitude adalah sikap dan kesediaan bereaksi terhadap suatu hal (Sukanti, Sumarsih, Siswanto \& Widayati, 2008).

Dari semua indikator yang sudah dianalisis dapat disimpulkan bahwa taruna memiliki knowledge, skill dan attitude yang tinggi dalam melaksanakan pembelajaran online, maka dari itu dapat diketahui jika taruna tidak memiliki kesulitan dalam menjalankan pembelajaran online yang diberikan selama pandemi covid-19.

Untuk mengetahui jumlah taruna berdasarkan kompetensinya dapat digolongkan melalui tabel yang diperoleh dari jumlah nilai pada setiap pertanyaa taruna maka didapatkan hasil sebagai berikut.

Tabel 5. Penggolongan Skor Kompetensi Taruna

\begin{tabular}{cccc}
\hline Kategori & Rentang Nilai & Jumlah Taruna & Persentase \\
\hline Tidak Kompeten & $0-25$ & 1 & $2,4 \%$ \\
\hline Kurang Kompeten & $26-50$ & 4 & $9,8 \%$ \\
\hline Sangat Kompeten & $51-75$ & 36 & $87,8 \%$ \\
\hline
\end{tabular}

Hasil analisis tiap indikator variabel kompetensi menunjukkan bahwa hampir semua responden memiliki intensitas kompetensi dalam kategori sangat kompeten. Dilihat dari indikator-indikatornya yaitu knowladge, skill dan attitude yakni, kategori tidak kompeten ada 1 orang dengan presentase $(2,4 \%)$, kategori kurang kompeten ada 4 orang dengan presentase $(9,8 \%)$, sedangkan untuk kategori sangat kompeten ada 36 orang dengan presentase $(87,8 \%)$.Kompetensi yang didapat akan mendukung keberhasilan dalam mencapai tujuan pembelajaran. Sebaliknya jika kompetensi yang dituntut kurang atau tidak mendukung keberhasilan pencapaian tujuan pembelajaran maka akan menimbulkan presepsi negatif dari peserta didik. 
Berdasarkan hasil data yang diperoleh menunjukkan bahwa Taruna Poltekip berkompeten dalam melaksanakan pembelajaran online ditengah pandemi Covid19, sehingga kompetensi taruna memiliki dampak langsung atas pembelajaran yang menjadi tanggung jawabnya. Tinggi tidaknya atau ukuran kompetensi taruna akan berdampak pada kualitas hasil pembelajaran yang dilakukan. Suatu kompetensi ini dapat diperoleh dengan proses aktualisasi pada individu itu sendiri, bisa melalui proses belajar, berdasarkan pengalaman. Selain itu dengan mengetahui penskoran kompetensi taruna tersebut dapat dijadikan evaluasi pembelajaran, pembentukan dan pengembangan lembaga pendidikan.

\section{KESIMPULAN}

Secara keseluruhan Taruna Poltekip dalam melaksanakan pembelajaran online sangat berkompeten yang dilihat dari setiap indikator atau dimensi teori kompetensi dan dilakukan skoring kompetensi. Sehingga taruna dalam melaksanakan pembelajaran online ini dengan penuh rasa tanggung jawab, terampil dan memiliki etika walaupun pembelajaran dilakukan dirumah masingmasing. Artinya walaupun pembelajaran dilaksanakan secara daring,taruna memiliki kompetensi yang sangat kompeten hal tersebut juga merupakan motto Taruna Poltekip yaitu tanggap, tanggon trengginas dan welas asih sehingga bagaimanapun keadaanya baik itu hal yang baru dan kebiasaan baru namun Taruna dapat melaksakan dan menyesuaikan hal yang baru serta tidak menjadi hambatan bagi taruna dalam melakukan pembelajaran online hal tersebut juga didukung dengan media pembelajaran yang diberikan cukup efektif dan efesien sehingga taruna dapat mudah memahami materi yang disampaikan, hal tersebut dikarenakan proses pembelajaran akan berjalan efektif dan efisien bila didukung dengan tersedianya media yang menunjang. Penyediaan media serta metodologi pendidikan yang dinamis, kondusif serta dialogis sangat diperlukan bagi pengembangan potensi peserta didik, secara optimal Hal ini disebabkan karena potensi peserta didik akan lebih terangsang bila dibantu dengan sejumlah media atau sarana dan prasarana yang mendukung proses interaksi yang sedang dilaksanakan.

\section{REFERENSI}

Amalia, L., \& Suwatno, S. (2016). Peningkatan kompetensi siswa melalui efektivitas competency based training. Jurnal Pendidikan Manajemen Perkantoran (JPManper), 1(1), 30-37.

Arikunto, S. (2006). Prosedur Penelitian Suatu Pendekatan Praktek. Jakarta: Rineka Cipta.

Arsyad, A. (2009). Media Pembelajaran. Jakarta: Grafindo Persada.

Azwar, S. (2004). Reliabilitas dan Validitas. Yogyakarta: Pustaka Pelajar.

Hidayat, R. H. (2020). Langkah-Langkah Strategis untuk Mencegah Pandemi Covid-19 di Lembaga Pemasyarkatan Indonesia. Jurnal Pendidikan Kesehatan, 9(1), 43-55.

Hutapea, P. d. (2008). Kompetensi Komunikasi Plus: Teori, Desain, Kasus dan Penerapan untuk HR dan Organisasi yang Dinamis. Jakarta: Gramedia Pustaka utama. 
Kandou, Y. L. (2016). Pengaruh knowledge management, skill dan attitude terhadap kinerja karyawan (studi pada PT. Bank Sulutgo Kantor Pusat di Manado). Jurnal Berkala Ilmiah Efisiensi, 16(1), 147-158.

Lubis, R. M., \& Oktaviani, S. (2015). Gambaran Tingkat Pengetahuan Perawat di Ruang Rawat Inap Lantai 8B RSUD Koja Jakarta Tentang Bantuan Hidup Dasar (BHD). Jurnal Akademi Keperawatan Husada Karya Jaya, 1(2), 2125.

Noor, K. B. M., \& Dola, K. (2009). Job competencies for malaysian managers in higher education institution. Asian Journal of Management and Humanity Sciences, 4(4), 226-240.

Spencer, L. M., \& Spencer, P. S. M. (2008). Competence at Work models for superior performance. USA: John Wiley \& Sons.

Sukanti, S., Sumarsih, S., Siswanto, S., \& Widayati, A. (2008). Persepsi Mahasiswa Program Studi Pendidikan Akuntansi Fise UNY terhadap Profesionalitas Guru Berdasarkan Undang-undang Guru dan Dosen No 14 Tahun 2005. Jurnal Pendidikan Akuntansi Indonesia, 6(2), 70-81.

Suryabrata, S. (2002). Pengembangan Alat Ukur Psikologis. Yogyakarta: ANDI. Suryabrata, S. (2010). Metodologi Penelitian. Jakarta: Rajawali Pers. 